\title{
Degradação ruminal da silagem de capim elefante com diferentes componentes de algaroba
}

\author{
Ruminal degradation of silage of elephant grass with mesquite different components
}

\author{
SANTOS, dos Suely ${ }^{1 *}$; SANTOS-CRUZ, Cristiane Leal dos ${ }^{1}$; ROCHA, Jefferson \\ Bomfim $^{1}$; PIRES, Aureliano José Vieira ${ }^{1}$; SANTOS, Ívina Paula Almeida ${ }^{1}$; LIMA, \\ Thiago Ramos ${ }^{1}$; JUNQUEIRA, Rodrigo Soares ${ }^{1}$
}

\begin{abstract}
${ }^{1}$ Universidade Estadual do Sudoeste da Bahia, Unidade Experimental de Caprinos e Ovinos, Departamento de Tecnologia Rural e Animal, Itapetinga, Bahia, Brasil.

*Endereço para correspondência: suyzootec@hotmail.com
\end{abstract}

\section{RESUMO}

Objetivou-se avaliar a degradabilidade ruminal da matéria seca, da proteína bruta e da fibra em detergente neutro da silagem de capim elefante com diferentes componentes de algaroba. Utilizou-se o delineamento inteiramente casualizado, com 4 tratamentos e 12 repetições, sendo as silagens: $100 \%$ de capim elefante; $70 \%$ de capim elefante $+30 \%$ de farelo de algaroba integral; $70 \%$ de capim elefante $+30 \%$ de vagem de algaroba; $70 \%$ de capim elefante + $30 \%$ de amido de algaroba. O capim elefante foi cortado com 100 dias após a rebrota, triturado e ensilado com os componentes de algaroba. Após 60 dias, os silos foram abertos e as amostras foram coletadas para a pré-secagem, moagem e posteriores análises e incubação. Amostras de cada silagem foram incubadas no rúmen de três novilhos Gir X Holandês, por períodos de $0 ; 3$; $6 ; 12 ; 24 ; 48 ; 72 ; 96 ; 120$ e 144 horas. Para o conjunto de parâmetros de degradação estudado, observou-se que os diferentes componentes de algaroba na silagem de capim elefante aumentaram a degradabilidade potencial e efetiva, a degradabilidade ruminal da matéria seca e proteína bruta. A maior degradabilidade foi observada na silagem com amido de algaroba. A algaroba e seus componentes constituem uma alternativa viável a ser adicionada na silagem de capim elefante, contudo, o amido de algaroba é mais eficiente.
The objective was to evaluate the degradability of dry matter, crude protein and neutral detergent fiber of elephant grass silage with different components of mesquite. It was used a completely randomized design with twelve treatments and four replications, and silages: $100 \%$ elephant grass, elephant grass $70 \%+30 \%$ bran full mesquite, $70 \%$ of elephant grass + $30 \%$ pods mesquite, $70 \%$ of elephant grass + $30 \%$ starch mesquite. The elephant grass was cut to 100 days after sprouting, and ensiled with crushed mesquite components. After 60 days, the silos were opened and samples were collected for pre-drying, grinding and subsequent analysis and incubation. Samples of each silage were incubated in the rumen of three steers Holstein X Gir for periods of $0,3,6,12$, $24,48,72,96,120$ and 144 hours. For the set of degradation parameters studied, it was observed that the different components of mesquite in the elephant grass silage increased the potential degradability and effectively increases the degradability of dry matter and crude protein. The higher degradability was observed in mesquite starch silage. The mesquite and its components constitute a viable alternative to be added in the elephant grass silage, however, mesquite starch is more efficient.

Keywords: conservation, in situ, Pennisetum purpureum Schum, Prosopis juliflora

Palavras-chave: conservação, in situ,

Pennisetum purpureum Schum, Prosopis julifloraSUMMARY 


\section{INTRODUÇÃO}

O armazenamento de forragem na forma de silagem constitui-se uma prática adotada para minimizar os problemas ocasionados pela estacionalidade de produção de forragem no Brasil. Uma das alternativas é a utilização da silagem de capim elefante (Pennisetum purpureum, Schum.), na forma de silagem, já que essa gramínea é bastante difundida no Nordeste por apresentar fácil implantação, proporcionar elevada produção de forragem e ser bem adaptada à região (RÊGO et al., 2011). Diversas pesquisas têm sido direcionadas ao desenvolvimento de tratamentos que garantam boas condições para o processo fermentativo e a manutenção da qualidade nutricional das silagens de capim elefante. Esses tratamentos envolvem, entre outras técnicas, a adição de materiais com altos teores de matéria seca (BERNARDINO et al., 2005; BATISTA et al., 2006) e de fontes de carboidratos solúveis (ANDRADE \& MELOTTI, 2004; FERREIRA et al., 2004; RODRIGUES et al., 2005). Dentre os vários alimentos alternativos disponíveis, a algaroba e seus componentes podem ser utilizados para o fornecimento de carboidratos solúveis em silagens de capim elefante.

A algarobeira (Prosopis juliflora) é uma leguminosa bastante difundida no Nordeste brasileiro, que produz frutos que medem até $20 \mathrm{~cm}$ de comprimento, com uma produção de vagens de 2 a 8 toneladas por hectare. As vagens de algaroba, quando maduras, possuem teores de matéria seca próximos a $84,0 \%$ e elevado teor de sacarose (SILVA et al., 2001).
A estimativa da degradação ruminal dos alimentos tem sido fundamental para avaliar a quantidade de nutrientes disponíveis para os micro-organismos do rúmen e sua qualidade (MOREIRA et al., 2003). A técnica de degradabilidade in situ permite avaliar a qualidade do nutriente, como, por exemplo, da proteína bruta que escapa da fermentação ruminal, e fornece, consequentemente, aminoácidos disponíveis para digestão a partir do abomaso (MOLINA et al., 2002; MOREIRA et al., 2003)

Além disso, o conhecimento do valor nutritivo potencial dos alimentos, por meio da degradação ruminal, permite o emprego racional dos mesmos, como alimento único ou como ingrediente de misturas mais complexas (CABRAL et al., 2005).

Objetivou-se avaliar a degradabilidade ruminal da matéria seca (DMS), da proteína bruta (DPB) e da fibra em detergente neutro (DFDN) da silagem de capim elefante com diferentes componentes de algaroba.

\section{MATERIAL E MÉTODOS}

O experimento foi desenvolvido nos laboratórios da Unidade Experimental de Caprinos e Ovinos - UECO, Laboratório de Forragicultura e Pastagem da Universidade Estadual do Sudoeste da Bahia - UESB, Campus Juvino Oliveira, no município de Itapetinga, BA. Foi utilizado o capim elefante (Pennisetum purpureum Schum. cv. Napier) proveniente de capineira já estabelecida no próprio campus da Universidade.

No momento do corte, o capim elefante apresentou $1,80 \mathrm{~m}$ de altura e foi cortado manualmente, após 100 dias de desenvolvimento e, em seguida, picado em partículas de $2 \mathrm{~cm}$, em máquina ensiladeira acoplada ao trator. Os 
componentes da algaroba (farelo de algaroba integral, vagem de algaroba picada e amido de algaroba - resíduo obtido através do processo de trituração da algaroba) foram adquiridos na Empresa RIOCON Fazendas Reunidas Rio de Contas Ltda, na cidade de Manoel Vitorino, BA. Antes da ensilagem, foram colhidas amostras do capim elefante e dos componentes de algaroba para determinação da composição químico-bromatológica.

$\mathrm{O}$ delineamento experimental foi o inteiramente casualizado com parcelas subdivididas, tendo os tempos nas subparcelas. $\mathrm{O}$ experimento foi constituído de quatro tratamentos, com 12 repetições por tratamento, o que totalizou 48 unidades experimentais. As silagens foram compostas por: a) $100 \%$ de capim elefante (CE); b) $70 \%$ de capim elefante $+30 \%$ de farelo de algaroba integral (FA); c) 70\% de capim elefante $+30 \%$ de vagem de algaroba (VA); d) $70 \%$ de capim elefante $+30 \%$ de amido de algaroba (AA) ensilados com base na MS. O material foi pesado e homogeneizado de acordo com as silagens e, posteriormente, compactado nos silos com a utilização de "soquetes" de concreto e pisoteio humano. Em seguida, ensilado em tambores de alumínio, com capacidade de 200 litros, compactado a uma densidade de $500 \mathrm{~kg} / \mathrm{m}^{3}$, vedados com lona plástica e armazenados por 60 dias.

Após o período de armazenamento, os silos foram abertos e aproximadamente $500 \mathrm{~g}$ de amostras foram colhidas e acondicionadas em freezer até présecagem. As amostras das silagens foram descongeladas à temperatura ambiente, por um período de, aproximadamente, 12 horas, e présecas, por 72 horas, em estufa de ar forçado, regulada para $55^{\circ} \mathrm{C}$. Em seguida, foram moídas em moinho tipo Willey, com peneira de $2 \mathrm{~mm}$, e as amostras proporcionais de cada repetição, por tratamento individual, foram misturadas e obtidas compostas de cada tratamento, as quais foram destinadas à incubação ruminal.

Os valores obtidos nas análises feitas do capim elefante, dos componentes de algaroba antes de ensilar estão descritos na (Tabela 1) e das silagens utilizadas na incubação ruminal estão descritos na (Tabela 2).

Os teores de matéria seca (MS), proteína bruta $(\mathrm{PB})$, extrato etéreo $(\mathrm{EE})$, matéria mineral $(\mathrm{MM})$, matéria orgânica (MO) foram determinados segundo metodologias descritas pela AOAC (2005). Já os teores de fibra em detergente neutro (FDN), fibra em detergente ácido (FDA) foram determinadas de acordo com a metodologia de Van Soest et al. (1991), os valores de nitrogênio insolúvel em detergente ácido (NIDA) e nitrogênio insolúvel em detergente neutro (NIDN) determinados segundo a metodologia descrita por Licitra et al. (1996) e os carboidratos totais e carboidratos não fibrosos foram determinados segundo Sniffen et al. (1992).

Para a incubação in situ, foram utilizados três novilhos mestiços (Gir x Holandês), fistulados no rúmen, com peso corporal médio de $480 \pm 18 \mathrm{~kg}$, mantidos em pastagem de Brachiaria decumbens, fornecida ad libitum, e $1 \mathrm{~kg}$ de concentrado à base de milho, farelo de soja e mistura mineral. Foram utilizados sacos de náilon nas dimensões de $7 \mathrm{x}$ $13 \mathrm{~cm}$, com porosidade de $50 \mu \mathrm{m}$, e acondicionou-se em cada saco, uma quantidade de $5 \mathrm{~g}$ de $\mathrm{MS} / \mathrm{saco}$, de modo a proporcionar cerca de 10 a $20 \mathrm{mg}$ de amostra $/ \mathrm{cm}^{2}$ de área útil dos sacos (NOCEK, 1988). Os sacos de todos os tratamentos foram inseridos no rúmen de cada animal por intermédio da fístula ruminal e por tempo de incubação, fixados a uma corrente de aço, nos 
Rev. Bras. Saúde Prod. Anim., Salvador, v.13, n.1, p.123-136 jan/mar, 2012 http://www.rbspa.ufba.br ISSN 15199940

tempos $0 ; 3 ; 6 ; 12 ; 24 ; 48 ; 72 ; 96 ; 120$ e 144 horas, em um total de 40 incubações por animal. Para o tempo correspondente à zero hora, os sacos foram colocados no rúmen e, rapidamente retirados e, posteriormente, colocados em água fria e em seguida lavados manualmente em água corrente, até a água sair limpa. A incubação foi realizada de forma a se retirar todos os sacos de náilon ao mesmo tempo, o que promoveu a lavagem uniforme do material.

Tabela 1. Composição dos materiais antes da ensilagem

\begin{tabular}{|c|c|c|c|c|}
\hline \multirow[b]{2}{*}{ Nutrientes $(\%)$} & \multirow[b]{2}{*}{$\begin{array}{l}\text { Capim } \\
\text { elefante }\end{array}$} & \multicolumn{3}{|c|}{ Componentes de Algaroba } \\
\hline & & $\begin{array}{c}\text { Farelo de } \\
\text { algaroba }\end{array}$ & $\begin{array}{l}\text { Vagem de } \\
\text { algaroba }\end{array}$ & $\begin{array}{l}\text { Amido de } \\
\text { algaroba }\end{array}$ \\
\hline Matéria seca & 23,6 & 84,2 & 76,8 & 83,4 \\
\hline Proteína bruta $^{1}$ & 4,6 & 10,8 & 10,8 & 10,0 \\
\hline Extrato etéreo $^{1}$ & 2,9 & 3,4 & 1,6 & 1,9 \\
\hline Matéria mineral $^{1}$ & 11,6 & 4,0 & 4,1 & 4,3 \\
\hline Matéria orgânica $^{1}$ & 88,4 & 96,0 & 95,9 & 95,7 \\
\hline Fibra em detergente neutro ${ }^{1}$ & 76,2 & 37,8 & 32,0 & 10,6 \\
\hline Fibra em detergente ácido ${ }^{1}$ & 56,6 & 28,2 & 22,3 & 7,2 \\
\hline Celulose $^{1}$ & 44,0 & 22,9 & 17,6 & 5,6 \\
\hline Hemicelulose $^{1}$ & 19,7 & 9,6 & 9,7 & 4,4 \\
\hline Lignina $^{1}$ & 8,3 & 5,00 & 4,3 & 1,2 \\
\hline FDNcp $^{1}$ & 70,6 & 33,9 & 28,6 & 9,2 \\
\hline $\mathrm{NIDA}^{2}$ & 13,2 & 3,8 & 4,0 & 0,6 \\
\hline $\mathrm{NIDN}^{2}$ & 20,6 & 10,7 & 11,1 & 0,8 \\
\hline Carboidratos totais ${ }^{1}$ & 80,9 & 81,8 & 83,5 & 83,8 \\
\hline Carboidratos não fibrosos ${ }^{1}$ & 4,7 & 44,0 & 51,5 & 73,2 \\
\hline
\end{tabular}

Tabela 2. Composição bromatológica das silagens de capim elefante com diferentes componentes de algaroba, utilizadas na incubação ruminal

\begin{tabular}{lcccc}
\hline & \multicolumn{4}{c}{ Silagens } \\
\cline { 2 - 5 } Nutrientes $^{1}$ & \multirow{2}{*}{$100 \% \mathrm{CE}$} & $70 \% \mathrm{CE}+$ & $70 \% \mathrm{CE}+$ & $70 \% \mathrm{CE}+$ \\
& & $30 \% \mathrm{FA}$ & $30 \% \mathrm{VA}$ & $30 \% \mathrm{AA}$ \\
\hline Matéria seca & 23,0 & 37,3 & 36,2 & 36,7 \\
Matéria orgânica & 88,5 & 90,3 & 89,3 & 90,9 \\
Proteína bruta & 3,7 & 9,7 & 8,8 & 9,7 \\
Extrato etéreo & 2,2 & 2,4 & 2,2 & 1,9 \\
Matéria mineral & 11,5 & 9,7 & 10,7 & 9,1 \\
Fibra em detergente neutro & 79,9 & 61,3 & 64,6 & 52,5 \\
Fibra em detergente ácido & 69,1 & 53,5 & 55,0 & 43,9 \\
Celulose & 50,8 & 40,5 & 42,3 & 34,2 \\
Hemicelulose & 10,8 & 7,8 & 9,5 & 8,6 \\
Lignina & 14,0 & 12,2 & 11,0 & 7,9 \\
\hline
\end{tabular}


$\mathrm{CE}=$ capim elefante; $\mathrm{FA}=$ farelo de algaroba; $\mathrm{VA}=$ vagem de algaroba; $\mathrm{AA}=$ amido de algaroba.

${ }_{1}^{1} \%$ da matéria seca.

As amostras foram colocadas em estufa a $55^{\circ} \mathrm{C}$, por 72 horas, e o resíduo obtido após esta etapa foi utilizado para as análises, uma parte para determinação de matéria seca em estufa de $105^{\circ} \mathrm{C}$ e a outra parte para determinação dos teores de proteína bruta de acordo com AOAC (2005) e fibra em detergente neutro, segundo metodologias descritas por Van Soest et al. (1991).

Os dados de degradabilidade in situ da MS, PB e FDN foram obtidos pela diferença de peso, encontrada para cada componente, entre as pesagens efetuadas antes e após a incubação ruminal e expressos em porcentagem.

Nos resultados obtidos para degradabilidade em função dos períodos de incubação, utilizou-se o programa Sistema de Análises Estatísticas e Genéticas - SAEG (RIBEIRO JÚNIOR, 2001). Foram calculadas as taxas de degradação da MS, da PB e da FDN, mediante utilização da equação proposta por Ørskov \& McDonald (1979): $\mathrm{Dt}=\mathrm{A}+\mathrm{B}\left(1-\mathrm{e}^{-\mathrm{ct}}\right)$, em que: $\mathrm{Dt}=$ fração degradada no tempo $t(\%), a=$ fração solúvel $(\%) ; b=$ fração insolúvel potencialmente degradável (\%); $c=$ taxa de degradação da fração $b\left(\mathrm{~h}^{-1}\right)$; e $t=$ tempo h.

Os coeficientes não lineares, $a, b$ e $c$, foram estimados por meio de procedimentos interativos de GaussNewton. A degradabilidade efetiva (DE) da MS, da PB e da FDN, no rúmen, foi calculada por meio da utilização do modelo: $\mathrm{DE}=a+(b \times c) /(c+\mathrm{k})$, em que: $\mathrm{k}$ corresponde à taxa estimada de passagem das partículas no rúmen de 2, 5 e $8 \%$ por hora.

\section{RESULTADOS E DISCUSSÃO}

Os diferentes componentes de algaroba utilizados na ensilagem de capim elefante contribuíram para o acréscimo da fração "a" na degradabilidade ruminal da MS e PB das silagens. Esta fração representa a porção da planta que está prontamente disponível para os micro-organismos do rúmen. Segundo Tonani et al. (2001), o desaparecimento da fração "a" caracteriza a solubilização dos açúcares e compostos nitrogenados solúveis, remanescentes da fermentação no silo, constituída, principalmente, de sacarose, frutose, glicose e pequenas quantidades de manose e galactose. O aumento da fração solúvel "a" das silagens pode ser atribuído à maior proporção de carboidratos de rápida degradação presentes nos componentes de algaroba (44,0\% no farelo, $51,5 \%$ na vagem e $73,2 \%$ no amido de algaroba) comparadas ao capim elefante com 4,7\% (Tabela 1).

A silagem com amido de algaroba foi a que proporcionou maiores valores da fração "a" da degradabilidade da MS e PB das silagens, 47,3 e 45,9\%, respectivamente, uma vez que o amido de algaroba possui maiores proporção de nutrientes solúveis em comparação aos outros componentes.

Os valores observados para a fração solúvel na MS foram de 12,0\% nas silagens com $100 \%$ de capim elefante, 30,$4 ; 27,6$ e $47,3 \%$, nas silagens que continham farelo, vagem e amido de algaroba, respectivamente. Os valores de "a" encontrados na PB foram de 8,7; 36,$8 ; 16,5$ e $45,9 \%$ nestas silagens, respectivamente (Tabela 3). Parte da fração solúvel da $\mathrm{PB}$ está disponível na forma de nitrogênio não-proteico (NNP), como sugerem Sniffen et al. (1992), Cabral et al. (2003) e comprovado por Cabral et al. (2004), que encontraram $56,9 \%$ de NNP, quando fracionaram os compostos 
Rev. Bras. Saúde Prod. Anim., Salvador, v.13, n.1, p.123-136 jan/mar, 2012 http://www.rbspa.ufba.br ISSN 15199940

nitrogenados da silagem de capim elefante. Valor de "a" superior aos encontrados neste trabalho foi relatado por Chizzotti et al. (2005), que avaliaram a degradabilidade ruminal da silagem de capim elefante e verificaram valor de $29,3 \%$ de fração $\mathrm{A}$.

$\mathrm{O}$ nível de utilização da fração nitrogenada é importante na avaliação de alimentos e na especificação de exigências nutricionais dos ruminantes (ROSSI JÚNIOR et al., 1997). A flora microbiana do rúmen transforma nitrogênio não proteico e proteína degradável em proteína microbiana, desde que disponha de energia. Desta forma, a disponibilidade de energia e nitrogênio para os micro-organismos é determinada pelas taxas de degradação e passagem pelo rúmen, e influenciam a eficiência e a quantidade de proteína microbiana sintetizada.

Quanto ao coeficiente "a" da fração FDN, o maior valor observado foi para a silagem com amido de algaroba, $3,9 \%$, e o menor valor para a silagem com $100 \%$ de capim elefante, $0,8 \%$. O menor valor de "a", observado na silagem com $100 \%$ de capim elefante, deve-se ao maior teor de FDN nesta silagem.

Tabela 3. Estimativa dos parâmetros de degradabilidade ruminal da matéria seca (MS), da proteína bruta (PB) e da fibra em detergente neutro (FDN) das silagens de capim elefante com diferentes componentes de algaroba, incubadas no rúmen

\begin{tabular}{|c|c|c|c|c|}
\hline \multirow{3}{*}{ Silagem } & \multicolumn{3}{|c|}{ Parâmetro } & \multirow{3}{*}{$r^{2}$} \\
\hline & \multicolumn{3}{|c|}{ Degradabilidade da MS } & \\
\hline & $\mathrm{a}$ & $\mathrm{b}$ & $\mathrm{c}$ & \\
\hline $100 \% \mathrm{CE}$ & 12,0 & 41,3 & 0,0228 & 0,99 \\
\hline $70 \% \mathrm{CE}+30 \% \mathrm{FA}$ & 30,4 & 28,9 & 0,0380 & 0,99 \\
\hline $70 \% \mathrm{CE}+30 \% \mathrm{VA}$ & 27,6 & 31,1 & 0,0463 & 0,99 \\
\hline \multirow[t]{3}{*}{$70 \% \mathrm{CE}+30 \% \mathrm{AA}$} & 47,3 & 25,7 & 0,0520 & 0,97 \\
\hline & \multicolumn{3}{|c|}{ Degradabilidade da PB } & \\
\hline & $\mathrm{a}$ & $\mathrm{b}$ & $\mathrm{c}$ & \\
\hline $100 \% \mathrm{CE}$ & 8,7 & 48,7 & 0,0471 & 0,98 \\
\hline $70 \% \mathrm{CE}+30 \% \mathrm{FA}$ & 36,8 & 27,2 & 0,0539 & 0,98 \\
\hline $70 \% \mathrm{CE}+30 \% \mathrm{VA}$ & 16,5 & 45,0 & 0,0489 & 0,95 \\
\hline \multirow[t]{3}{*}{$70 \% \mathrm{CE}+30 \% \mathrm{AA}$} & 45,9 & 28,9 & 0,0589 & 0,94 \\
\hline & \multicolumn{3}{|c|}{ Degradabilidade da FDN } & \\
\hline & $\mathrm{a}$ & $\mathrm{b}$ & $\mathrm{c}$ & \\
\hline $100 \% \mathrm{CE}$ & 0,8 & 46,9 & 0,0255 & 0,99 \\
\hline $70 \% \mathrm{CE}+30 \% \mathrm{FA}$ & 3,1 & 39,0 & 0,0300 & 0,97 \\
\hline $70 \% \mathrm{CE}+30 \% \mathrm{VA}$ & 3,8 & 40,3 & 0,0390 & 0,99 \\
\hline $70 \% \mathrm{CE}+30 \% \mathrm{AA}$ & 3,9 & 41,2 & 0,0336 & 0,98 \\
\hline
\end{tabular}

$\mathrm{a}=$ fração solúvel (\%); $\mathrm{b}=$ fração insolúvel potencialmente degradável $(\%) ; \mathrm{c}=$ taxa fracional de degradação $\left(\mathrm{h}^{-1}\right)(\% /$ hora $) ; \mathrm{r}^{2}=$ coeficiente de determinação; $\mathrm{CE}=$ capim elefante; $\mathrm{FA}=$ farelo de algaroba; $\mathrm{VA}=$ vagem de algaroba; $\mathrm{AA}=$ amido de algaroba.

Quanto à fração “ $b$ ”, insolúvel potencialmente degradável, as silagens com $100 \%$ de capim elefante apresentaram valores superiores quando 
comparadas às demais silagens, tanto na MS quanto na PB. Os valores da fração " $b$ " para a MS variaram entre $25,7 \%$, na silagem com amido de algaroba, e $41,3 \%$, na silagem com $100 \%$ de capim elefante (Tabela 3). Para PB, ocorreu variação de 27,2 a 48,7\% nas mesmas silagens (Tabela 3). Estes resultados possivelmente ocorreram devido à maior proporção de FDN e NIDN na MS e PB do capim elefante, respectivamente. A silagem com $100 \%$ de capim elefante apresentou maior proporção $(46,9 \%) \mathrm{da}$ fração potencialmente degradável, "b", para FDN, e o menor valor foi observado na silagem que continha farelo de algaroba (Tabela 3). Possivelmente, o alto teor de FDN, presente no capim elefante (Tabela 1) contribuiu para estes resultados.

As taxas de degradação em $\% / \mathrm{h}$, fração $c$, da MS foi mais elevada na silagem que continha amido de algaroba, $5,2 \% / \mathrm{h}$, seguida da silagem com vagem de algaroba $4,6 \% / \mathrm{h}$, farelo de algaroba, $3,8 \% / \mathrm{h}$ e, depois, a silagem com $100 \%$ de capim elefante, $2,3 \% / \mathrm{h}$ (Tabela 3 ). Chizzotti et al. (2005) avaliaram a degradabilidade ruminal da silagem de capim elefante e observaram taxa de passagem da MS semelhante (2,36\%). Certamente, a pior qualidade do capim utilizado pelos autores, com mais de $10 \%$ de lignina, contribuiu para a menor fração $c$. Neste estudo, o teor de lignina do capim elefante pode ter influenciado para o menor teor desta fração. As taxas de degradação da $\mathrm{PB}$, em $\% / \mathrm{h}$, fração $c$, foram mais elevadas nas silagens com amido de algaroba, 5,8\%/h (Tabela 3 ).

Para a FDN, maiores valores da taxa de degradação, fração "c", foram observados nas silagens com diferentes componentes de algaroba, com 3,0; 3,9 e $3,4 \% / \mathrm{h}$ para as silagens com farelo, vagem e amido de algaroba, respectivamente. A menor taxa de degradação foi verificada na silagem com $100 \%$ de capim elefante, $2,6 \% / \mathrm{h}$ (Tabela 3). A proporção de carboidratos da parede celular e o seu teor de lignina são os fatores que mais afetam a redução da qualidade das gramíneas tropicais. $\mathrm{O}$ maior teor de lignina presente no capim elefante foi, possivelmente, a causa da menor taxa de degradação, fração "c", no presente estudo.

A degradação potencial (DP) da matéria seca aumentou com a inclusão dos diferentes componentes de algaroba na ensilagem de capim elefante, com valor máximo obtido de $73,0 \%$, quando adicionado o amido de algaroba, $59,3 \%$ na silagem com farelo de algaroba, $58,7 \%$ na silagem com vagem de algaroba e a silagem com $100 \%$ de capim elefante obteve o menor valor, 53,3\% (Tabela 4).

A degradabilidade potencial (DP) da PB obteve resultado semelhante à degradabilidade potencial da MS entre as silagens. Entretanto, a DP da fração FDN foi maior para a silagem com $100 \%$ de capim elefante, $47,7 \%$, seguida da silagem com amido de algaroba, 45,1\%, com a vagem de algaroba, $44,0 \%$ e com farelo de algaroba 42,1\% (Tabela 4).

Sarti et al. (2005) avaliaram a degradabilidade ruminal do capim elefante e observaram degradabilidade potencial de $60 \%$ da FDN. Carvalho et al. (2008) relataram que, com o crescimento das plantas, a parede celular se desenvolve e acumula lignina. Portanto, acredita-se que o estágio de maturação em que o capim elefante foi cortado, neste experimento, aos 100 dias após o corte de uniformização, tenha sido a causa dos menores valores de DP da FDN, como observado no trabalho de Rêgo et al. (2011). Os maiores valores de DP da PB verificados nesta pesquisa podem estar relacionados com os maiores teores de 
Rev. Bras. Saúde Prod. Anim., Salvador, v.13, n.1, p.123-136 jan/mar, 2012 http://www.rbspa.ufba.br ISSN 15199940

proteína presentes nos componentes de algaroba.

Tabela 4. Degradabilidade potencial (DP) e efetiva (DE) da matéria seca (MS), da proteína bruta $(\mathrm{PB})$ e da fibra em detergente neutro (FDN) das silagens de capim elefante com diferentes componentes de algaroba, calculadas para taxas de passagem de 2,5 e $8 \% / h$

\begin{tabular}{|c|c|c|c|c|}
\hline \multirow{3}{*}{ Silagem } & \multirow{3}{*}{$\begin{array}{c}\text { Degradabilidade } \\
\text { potencial }\end{array}$} & \multicolumn{3}{|c|}{ Degradabilidade efetive } \\
\hline & & \multicolumn{3}{|c|}{ Taxa de passagem $(\% / h)$} \\
\hline & & 2 & 5 & 8 \\
\hline & \multicolumn{4}{|c|}{ Matéria seca (\%) } \\
\hline $100 \% \mathrm{CE}$ & 53,3 & 34,0 & 24,9 & 21,1 \\
\hline $70 \% \mathrm{CE}+30 \% \mathrm{FA}$ & 59,3 & 49,4 & 42,9 & 39,7 \\
\hline $70 \% \mathrm{CE}+30 \% \mathrm{VA}$ & 58,7 & 49,3 & 42,5 & 39,0 \\
\hline \multirow{2}{*}{$70 \% \mathrm{CE}+30 \% \mathrm{AA}$} & 73,0 & 65,9 & 60,4 & 57,4 \\
\hline & \multicolumn{4}{|c|}{ Proteína bruta $(\%)$} \\
\hline $100 \% \mathrm{CE}$ & 57,5 & 42,9 & 32,4 & 26,8 \\
\hline $70 \% \mathrm{CE}+30 \% \mathrm{FA}$ & 64,0 & 56,6 & 50,9 & 47,7 \\
\hline $70 \% \mathrm{CE}+30 \% \mathrm{VA}$ & 61,5 & 48,4 & 38,7 & 33,5 \\
\hline \multirow[t]{2}{*}{$70 \% \mathrm{CE}+30 \% \mathrm{AA}$} & 74,8 & 54,8 & 50,3 & 48,8 \\
\hline & \multicolumn{4}{|c|}{ Fibra em detergente neutro (\%) } \\
\hline $100 \% \mathrm{CE}$ & 47,7 & 27,1 & 16,6 & 12,1 \\
\hline $70 \% \mathrm{CE}+30 \% \mathrm{FA}$ & 42,1 & 26,5 & 17,7 & 13,8 \\
\hline $70 \% \mathrm{CE}+30 \% \mathrm{VA}$ & 44,0 & 30,4 & 21,4 & 16,9 \\
\hline $70 \% \mathrm{CE}+30 \% \mathrm{AA}$ & 45,1 & 29,7 & 20,5 & 16,1 \\
\hline
\end{tabular}

A degradabilidade efetiva (DE) foi estimada considerando as taxas de passagem de 2, 5 e $8 \% /$ hora. De acordo com Aroeira et al. (1996), a degradabilidade efetiva de um alimento pode ser considerada como a energia digerida no rúmen, portanto, a ingestão de alimentos com maior degradabilidade da MS, PB e da fibra proporciona maior energia disponível aos micro-organismos. A utilização dos diferentes componentes de algaroba na ensilagem do capim elefante aumentou a degradabilidade efetiva das silagens. A degradabilidade efetiva decresceu à medida que aumentou a taxa de passagem (k) para todas as silagens estudadas. A silagem que continha amido de agaroba apresentou maiores valores, 65,$9 ; 60,9$ e $57,4 \%$, de degradabilidade efetiva da MS e a silagem com $100 \%$ de capim elefante obteve os menores valores 34,$0 ; 24,9$ e $21,1 \%$ nas taxas de passagem de 2,5 e $8 \% /$ hora, respectivamente (Tabela 4). Rodrigues et al. (2004) sugeriram que a elevada proporção de carboidratos da parede celular e o teor de lignina da forragem são a principal causa da menor degradabilidade. Assim, os menores valores de degradabilidade efetiva da MS, observados na silagem com 100\% de capim elefante, podem ser atribuídos à maior proporção destes constituintes. A degradabilidade efetiva da PB aumentou nas silagens de capim elefante 
com os componentes de algaroba, cujos valores variaram de 26,8 a $56,6 \%$ para as taxas de passagens estudadas. Os valores de degradação da PB, aqui observados, podem ser atribuídos ao menor ou maior incremento de NNP das silagens, em decorrência da proteólise durante a fermentação no silo.

A degradabilidade efetiva da FDN variou entre as silagens para as diferentes taxas de passagem. Os valores mais elevados foram observados nas silagens com vagem e amido de algaroba, 30,4 e $29,7 \%$, respectivamente, na taxa de $2 \%$. Já nas taxas de 5 e $8 \%$, a degradabilidade efetiva reduziu nestas silagens. Semelhantemente foi verificado nas outras silagens que obtiveram os menores valores da degradabilidade efetiva nas mesmas taxas de passagem. A silagem de capim elefante obteve valores da degradabilidade efetiva próximos aos das silagens que tiveram incluídos os diferentes componentes de algaroba.
As curvas de degradação da MS, ajustadas para cada silagem em função dos períodos de incubação, mostraram que a utilização dos diferentes componentes de algaroba na silagem de capim elefante aumentou a degradabilidade da MS (DMS) das silagens (Figura1). Os dados mostram, também, que a silagem com a fração amido de algaroba apresentou maior DMS no rúmen.

A silagem com $100 \%$ de capim elefante apresentou o pico de degradação da MS após 138 horas de incubação, com valor de degradação igual a 51,5\%, enquanto nas silagens que continham os componentes de algaroba foi no período 96 horas de incubação que ocorreu o potencial máximo de degradação. Isso pode ter acontecido em função da maior proporção de nutrientes solúveis presentes nas frações de algaroba.

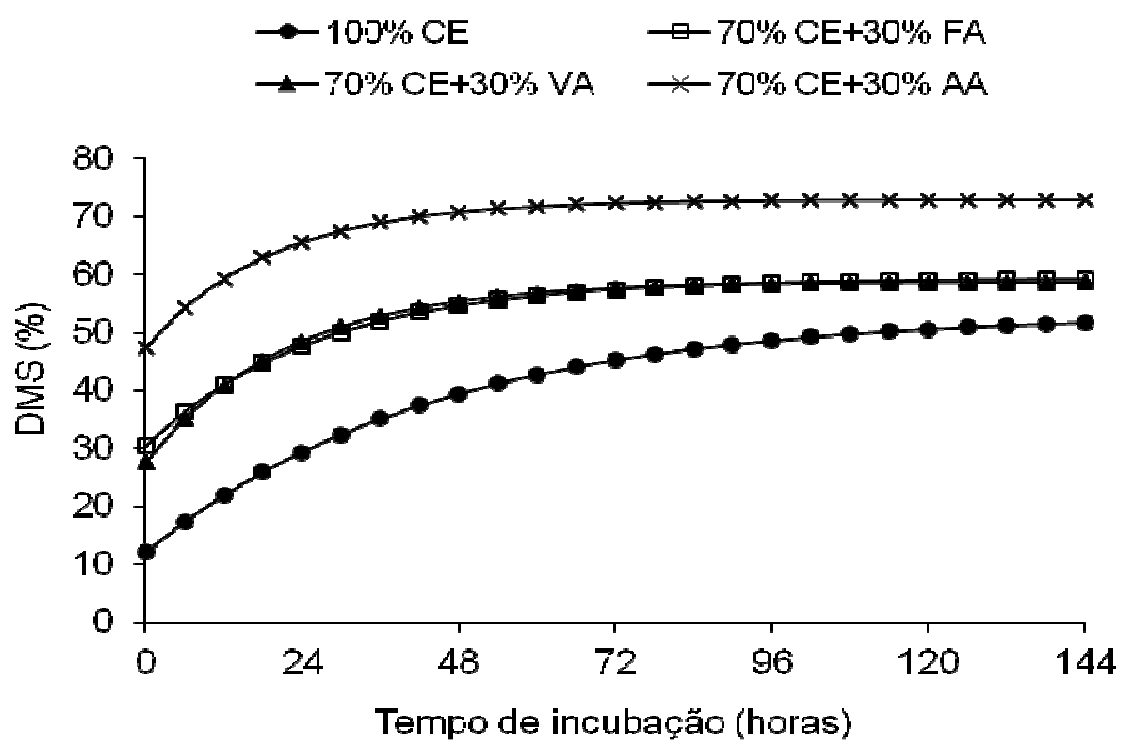

Figura 1. Degradabilidade da matéria seca (DMS) de silagens de capim elefante com diferentes componentes de algaroba, em função dos períodos de incubação no rúmen, estimada pela equação: $A+B\left(1-e^{-c t}\right)$ 
A silagem com amido de algaroba atingiu cerca de $65 \%$ de degradação ruminal no período de 24 horas de incubação. As demais silagens, com farelo e vagem de algaroba, atingiram quase que $50 \%$, já na silagem apenas com capim elefante, o valor foi baixo, menos de 30\% neste mesmo período (Figura 1). Nota-se que a silagem que apresentou maior degradação ruminal (silagem com amido de algaroba), no período inicial, já obteve uma alta taxa de degradação da MS em função da maior proporção de carboidratos solúveis neste tratamento. Essa diferença na degradação ruminal da MS das silagens pode ser um importante fator a influenciar o consumo animal.

Rêgo et al. (2011), ao avaliarem o efeito dos níveis de adição do farelo da vagem de algaroba na degradabilidade da MS da silagem de capim elefante, nos diferentes tempos de incubação, verificaram que em todos os níveis de inclusão do farelo de algaroba, ocorreu aumento no desaparecimento da MS com o decorrer do tempo de incubação no rúmen.

Quando se observa a degradabilidade ruminal da PB (DPB) num intervalo de tempo (Figura 2), verifica-se que a silagem com amido de algaroba apresentou maior desparecimento da $\mathrm{PB}$, após 48 horas de incubação ruminal, com potencial máximo de degradação de $70 \%$. Provavelmente, a maior concentração de proteínas solúveis presente no amido de algaroba contribuiu para este resultado.

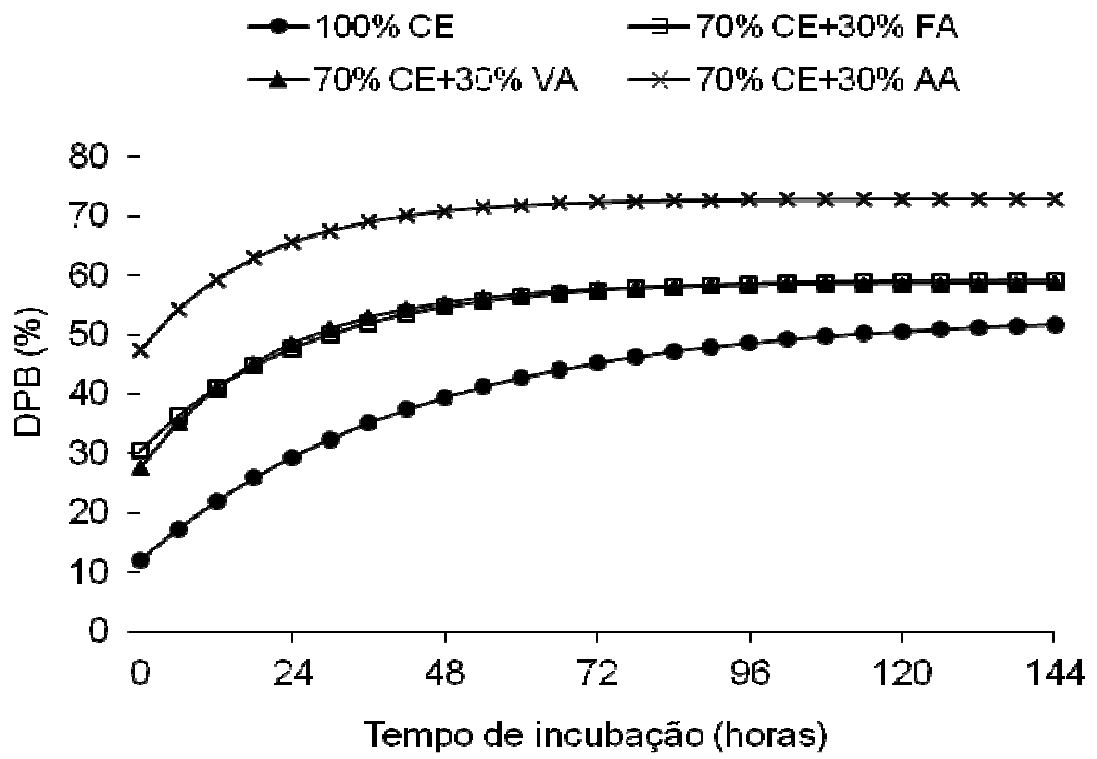

Figura 2. Degradabilidade da proteína bruta (DPB) de silagens de capim elefante com diferentes componentes de algaroba, em função dos períodos de incubação no rúmen, estimada pela equação: $A+B\left(1-e^{-c t}\right)$

As silagens em que foram incluídos farelo e vagem de algaroba obtiveram resultados semelhantes, com valores de degradação acima de $50 \%$ neste mesmo período. Já a silagem com $100 \%$ de capim elefante obteve menor valor de desaparecimento da proteína, com $48 \%$ no período de aproximadamente 96 
horas, o que estabilizou-se a partir das 132 horas de incubação ruminal, com $51 \%$.

Assim como ocorreu na MS, houve maior degradação da $\mathrm{PB}$ na silagem com amido de algaroba, com o aumento do tempo de incubação. Também ocorreu alta taxa de degradação no tempo inicial, devido à maior proporção de nutrientes solúveis presente nesta silagem.

A curva de desaparecimento da FDN (Figura 3) mostra que as silagens obtiveram resultados semelhantes quanto à taxa de desaparecimento da fibra.

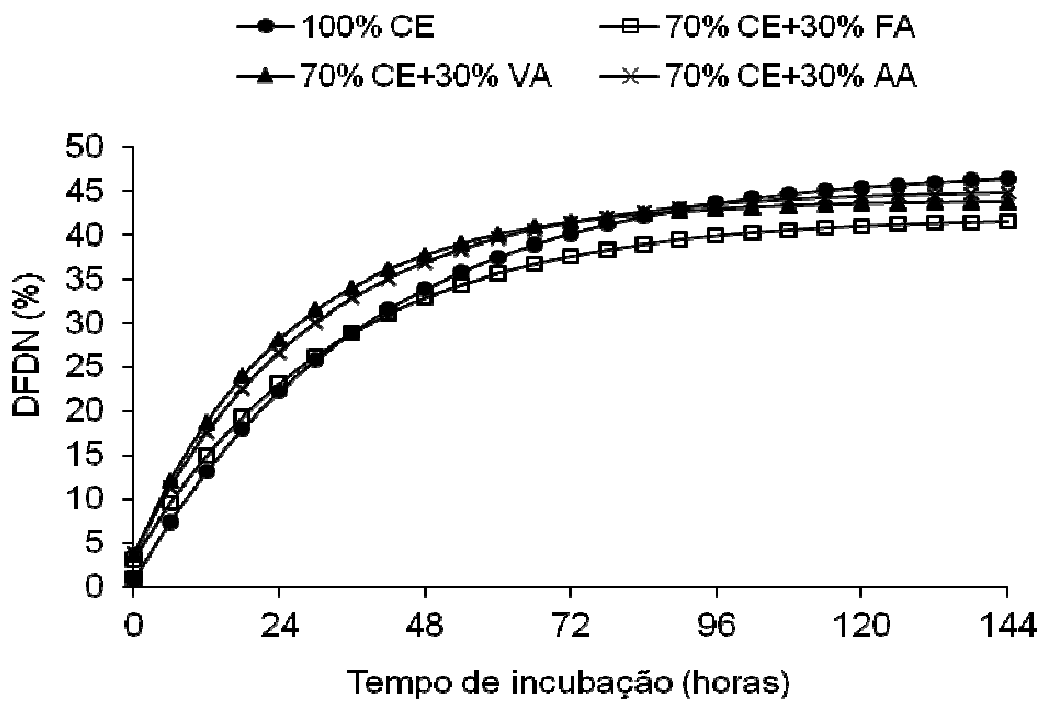

Figura 3. Degradabilidade da fibra em detergente neutro (FDN) de silagens de capim elefante com diferentes componentes de algaroba, em função dos períodos de incubação no rúmen, estimada pela equação: $A+B\left(1-e^{-c t}\right)$

A silagem apenas com capim elefante e as silagens com vagem de algaroba $\mathrm{e}$ amido de algaroba atingiram degradação de, aproximadamente, $40 \%$ no período próximo de 96 horas de incubação. Já aquela que continha farelo de algaroba, atingiu cerca de $35 \%$ neste mesmo período e, a partir deste tempo, os valores observados de degradação ruminal da FDN para as silagens foram maiores.

Resultados observados por Rêgo et al. (2011) demonstraram que, com o aumento dos tempos de incubação, as porcentagens de desaparecimento da FDN dos tratamentos em estudo aumentaram efetivamente até 96 horas de incubação.

Silagens elaboradas com capim elefante e diferentes componentes de algaroba possuem maior degradabilidade potencial e efetiva.

$\mathrm{O}$ amido de algaroba é o componente que melhor favorece a degradação ruminal das silagens.

\section{REFERÊNCIAS}

ANDRADE, S.J.T.; MELOTTI, L.

Efeito de alguns tratamentos sobre a 
Rev. Bras. Saúde Prod. Anim., Salvador, v.13, n.1, p.123-136 jan/mar, 2012 http://www.rbspa.ufba.br ISSN 15199940

qualidade da silagem de capim-elefante cultivar Napier (Pennisetum purpureum, Schum). Brazilian Journal of Veterinary Research and Animal Science, v. 41, p. 409-415, 2004.

AROEIRA, L.J.M.; LOPES, F.C.F.; DAYRELL, M.S. Degradabilidade de alguns alimentos no rúmen de vacas holandês/zebu. Revista da Sociedade Brasileira de Zootecnia, v. 25, n. 6, p. 1178-1186, 1996.

ASSOCIATION OF OFFICIAL ANALYTICAL CHEMISTS - AOAC. Officia methods of analysis.18.ed. Washington D.C., 2005.

BATISTA, A.M.V.; GUIM, A.; SOUZA, I.S.; LIRA, K.G.; SANTOS, M.V.F.; DUBEUX JÚNIOR, J.C.B. Efeitos da adição de vagens de algaroba sobre a composição química e a microbiota fúngica de silagens de capim-elefante. Revista Brasileira de Zootecnia, v.35, n.1, p.1-6, 2006.

BERNARDINO, F.S.; GARCIA, R.; ROCHA, F.C.; SOUZA, A.L.; PEREIRA, O.G. Produção e características do efluente e composição bromatológica da silagem de capimelefante contendo diferentes níveis de casca de café. Revista Brasileira de Zootecnia, v.34, n.6, p.2185-2191, 2005.

CABRAL, L.S.; VALADARES FILHO, S.C.; DETMANN, E. Composição químico-bromatológica, produção de gás, digestibilidade in vitro da matéria seca e NDT estimado da silagem de sorgo com diferentes proporções de panículas.

Revista Brasileira de Zootecnia, v.32, p.1250-1258, 2003.

CABRAL, L.S.; VALADARES FILHO, S.C.; DETMANN, E.; ZERVOUDAKIS, J.T.; VELOSO, R.G.; NUNES, P.M.M. Taxas de digestão das frações protéicas e de carboidratos para as silagens de milho e de capim-elefante, o feno de capimtifton-85 e o farelo de soja. Revista Brasileira de Zootecnia, v.33, n.6, p.1573-1580, 2004.

CABRAL, L.S.; VALADARES FILHO, S.C.; ZERVOUDAKIS, J.T.; SOUZA, A.L.; DETMANN, E. Degradabilidade in situ da matéria seca, da proteína bruta e da fibra de alguns alimentos. Pesquisa

Agropecuária Brasileira, v.40, n.8, p.777-781, 2005.

CARVALHO, G.G.P.; GARCIA, R. PIRES, A.J.V.; DETMANN, E.; PEREIRA, O.G.; FERNANDES, F.E.P. Degradação ruminal de silagem de capim-elefante emurchecido ou com diferentes níveis de farelo de cacau. Revista Brasileira de Zootecnia, v.37, n.8, p.1347-1354, 2008.

CHIZZOTTI, M.L.; VALADARES FILHO, S.C.; LEÃO, M.I.; VALADARES, R.F.D.; CHIZZOTTI, F.H.M.; MAGALHÃES, K. A.; MARCONDES, M. I. Casca de algodão em substituição parcial à silagem de capimelefante para novilhos. Consumo, degradabilidade e digestibilidade total e parcial. Revista Brasileira de Zootecnia, v.34, n.6, p.2093-2102, 2005.

FERREIRA, A.C.H.; NEIVA, J.N.M.; RODRIGUEZ, N.M.; LÔBO, R.N.B.; VASCONCELOS, V.R. Valor nutritivo das silagens de capimelefante com diferentes níveis de subprodutos da indústria do suco de caju. Revista Brasileira de Zootecnia, v.33, n.6, p.1380-1385, 2004.

LICITRA, G.; HERNANDEZ, T.M.; VAN SOEST, P.J. Standardization of 
Rev. Bras. Saúde Prod. Anim., Salvador, v.13, n.1, p.123-136 jan/mar, 2012 http://www.rbspa.ufba.br ISSN 15199940

procedures for nitrogen fractionation of ruminant feeds. Animal Feed

Science and Technology, v.57, p.347358, 1996.

MOLINA, L.R.; GONÇALVES, L.C.; RODRIGUEZ, N.M. Digestibilidade in situ das frações fibrosas de silagens de seis genótipos de sorgo (Sorghum bicolor (L.) Moench) em diferentes estádios de maturação.

Arquivo Brasileiro de Medicina Veterinária e Zootecnia, v.54, p.169-179, 2002.

MOREIRA, J.F.C.; RODRIGUEZ, N.M.; FERNANDES, P.C.C.

Concentrados protéicos para bovinos. 1. Digestibilidade in situ da matéria seca e da proteína bruta. Arquivo Brasileiro de Medicina Veterinária e Zootecnia, v.55, p.315-323, 2003.

NOCEK, J.E. In situ and other methods to estimate ruminal protein and energy digestibility. A review.

Journal of Dairy Science, v.71, p.2051-2069, 1988.

ØRSKOV, E.R.; McDONALD, I. The estimation of protein degradability in the rumen from incubation measurements weighted according to rate of passage. Journal of Agriculture Science, v.92, n.2, p.449-503, 1979.

RÊGO, A.C.; PAIVA, P.C.A.; MUNIZ, J.A.; VAN CLEEF, E.H.C.B.; MACHADO NETO, O.R. Degradação ruminal de silagem de capim-elefante com adição de vagem de algaroba triturada. Revista Ciência Agronômica, v.42, n.1, p.199-207, 2011.

RIBEIRO JÚNIOR, J.I. Análises estatísticas no SAEG - Sistema para análises estatísticas. Viçosa:
Universidade Federal de Viçosa, 2001. 301p.

RODRIGUES, A.L.P.; SAMPAIO, I.B.M.; CARNEIRO, J.C.

Degradabilidade in situ da matéria seca de forrageiras tropicais obtidas em diferentes épocas de corte.

Arquivo Brasileiro de Medicina Veterinária e Zootecnia, v.56, n.5, p.658-664, 2004.

RODRIGUES, P.H.M.; BORGATTI, L.M.O.; GOMES, R.W.; PASSINI, R.; MEYER, P.M. Efeito da adição de níveis crescentes de polpa cítrica sobre a qualidade fermentativa e o valor nutritivo da silagem de capimelefante. Revista Brasileira de Zootecnia, v.34, n.4, p.1138-1145, 2005 .

ROSSI JÚNIOR, P.; BOSE, M.L.V.; BOIN, C. Degradabilidade ruminal do amido de silagem de milho, farelo de soja e sorgo grão, em bovinos da raça nelore. Revista Brasileira de

Zootecnia, v.26, n.2, p.416-422, 1997.

SARTI, L.L.; JOBIM, C.C.; BRANCO, A.F. JACOBS, F. Degradação ruminal da matéria seca, da proteína bruta e da fração fibra de silagens de milho e de capim-elefante. Ciência Animal Brasileira, v.6, n.1, p.1-10, 2005.

SILVA, S.A.; SOUZA, A.G.; CONCEIÇÃO, M.M. Estudo termogravimétrico e calorimétrico da algaroba. Revista Química Nova, v.24, p.460-464, 2001.

SNIFFEN, C.J.; CONNOR, D.J.; VAN SOEST, P.J.; FOX, D.G.; RUSSEL, J.B.A net carbohydrate and protein system for evaluating cattle diets: 
Rev. Bras. Saúde Prod. Anim., Salvador, v.13, n.1, p.123-136 jan/mar, 2012 http://www.rbspa.ufba.br ISSN 15199940

carbohydrate and protein availability.

Journal of Animal Science, v.70, n.12, p.3562-3577, 1992.

TONANI, F.L.; RUGGIERI, A.C.; QUEIROZ, A.C. ANDRADE, P. Degradabilidade ruminal in situ da matéria seca e da fibra em detergente neutro em silagens de híbridos de sorgo colhidos em diferentes épocas. Arquivo Brasileiro de Medicina Veterinária e Zootecnia, v.53, n.1, p.100-104, 2001.
VAN SOEST, P.J.; ROBERTSON, J.B.; LEWIS, B.A. Methods for dietary fiber, neutral detergent fiber, and nonstarch polysaccharides in relation to animal nutrition. Journal of Animal Science, v.74, n.10, p.3583-3597, 1991.

Data de recebimento: 01/05/2011

Data de aprovação: 04/02/2012 